\title{
People Welfare And Province Financial Performance In Indonesia
}

\author{
Maryono $^{1}$, Ida Nurhayati ${ }^{2}$ and Batara Daniel Bagana ${ }^{3}$ \\ \{maryono@edu.unisbank.ac.id ${ }^{1}$; ida.nurhayati@edu.unisbank.ac.id²batara@edu.unisbank.ac.id ${ }^{3}$ \}
}

Faculty of Economics and Business Stikubank University Semarang Indonesia

\begin{abstract}
This study aims to analyze the development of the welfare of the Indonesian people and the financial performance of the provincial government in Indonesia. The population in this study covers all provinces in Indonesia totaling 34 provinces with observational years from 2016 to 2019. The data used in the form of secondary data sourced from the central statistical body and analyzed in a descriptive manner. The results showed that the welfare of Indonesian people nationally was included in the high category and every year it had increased. The average source of provincial government in Indonesia is still to rely on transfers from the central government. Provincial expenditure in general is allocated more for routine expenditure or indirect expenditure compared to direct expenditure allocation which gets a smaller share.
\end{abstract}

Keywords: people walfare, financial performance

\section{Introduction}

In 2019 for the first time Indonesia entered the ranks of countries with a high human development index (HDI) category. This certainly needs to be grateful for all the people of Indonesia that the efforts that have been implemented so far can produce tangible results in the form of increasing people's welfare status. To achieve this position is not an easy endeavor, because from 1990 the commencement of the recording of the human development index carried out by the United Nations Development Program (UNDP) in 2019 we can reach a high level in community welfare. Indonesia ranks 111 th out of 189 countries and Indonesia among ASEAN member countries falls under Singapore, Brunei Darussalam, Malaysia, Thailand and the Philippines.

There are three factors that encourage an increase in the human development index in Indonesia, namely health, education and the economy. For these three factors, Indonesia continues to experience progress from year to year. Human development in Indonesia continues to progress. In 2019, the Human Development Index (HDI) of Indonesia will reach 71.92. This figure increased by 0.53 points or grew by 0.74 percent compared to 2018 . Babies born in 2019 had hopes of being able to live up to 71.34 years, 0.14 years longer than those born the previous year. Children who are 7 years old in 2019 have the expectation of being able to enjoy education for 12.95 years (almost equivalent to the period of education to complete the Diploma I level), 0.04 years longer than those of the same age in 2018. Population age 25 years and over have on average been educated for 8.34 years (almost equivalent to the period of education to complete grade IX), 0.17 years longer than the previous year. In 2019, Indonesians meet their daily needs with an average per capita expenditure (PPP) of 11.30 million rupiah per year, an increase of 240 thousand rupiah compared to the previous year's expenditure. 
But that does not mean that the problems facing the Indonesian people have been resolved with this achievement. This fact must make the pumping spirit to move forward and work hard and work smartly so that people's welfare in the future will increase. One of the problems facing Indonesia today is the gap where there is still a gap between the central government, provincial governments and district / city governments. In addition, gaps also occur between regions such as western Indonesia and Eastern Indonesia territory or the gap between urban and rural communities.

The current policy adopted by the government by giving priority to the $3 \mathrm{~T}$ region, namely Behind, Outermost and Frontier has actually shown the results where the gap between regions is increasingly reduced. The one-price petroleum program has had an impact on increasing people's purchasing power due to falling prices for petroleum fuels and other commodity prices due to lower transportation costs. The Sea Toll Road program also has a significant impact on communities that have been isolated so that open routes can be opened or entered into other areas so that the traffic of goods needs to be more smooth and guaranteed.

An important indicator in measuring regional autonomy indicators is the increase in people's welfare, and the second is an increase in regional autonomy in financing regional expenditure. The results obtained from this study are whether it has improved people's welfare and regional fiscal independence from all provinces in Indonesia. The results of this study differed from all previous studies which only covered part of the area.Finally, the social safety net program that has been ongoing has been continued and improved so that people with a weak economy or low-income people can enjoy various programs provided by the government. These programs include, among others: direct cash assistance, the Smart Indonesia Card program, the Healthy Indonesia Card, the Hope Family Program, the village fund program which is increased annually. This is of course expected to be able to improve the welfare of the community at large so that the ideals of building a just and prosperous society can be realized.

\section{Literature Review}

\subsection{Goal Setting Theory}

The basis of goal-setting theory is that specific and difficult goals result in higher performance than just encouraging individuals to do their best. The goal of driving this higher performance is through four mechanisms. First, goals focus attention and effort towards activities that are relevant to the goal and away from other activities. Second, goals energize individuals to exert greater effort at more challenging goals. Third, goals increase the level of persistence that will be displayed by the individual to achieve the goal. Finally, the objective is indirectly the passion, discovery, and / or use of knowledge relevant to the task. In the current era of regional autonomy, every head of government, both central and regional, is doing their best to be able to realize the promises made during the campaign, especially those directly related to the welfare of the people. Like the current government which has focused on the development of the people, after five years previously it was focused on the development of infrastructure which indirectly was also aimed at improving the people's welfare. 


\subsection{Regional Autonomy}

Regional Autonomy according to Law No. 23 article 1 paragraph 6 of 2014 concerning Regional Government Chapter I general provisions are the rights, authorities and obligations of the Autonomous Region to regulate and manage government affairs and the interests of local communities in the State system. Autonomous regions in this definition are legal societies that have territorial boundaries. Granting the widest possible autonomy to Regional Original Revenue is directed at accelerating the realization of community welfare through improved services, empowerment, and community participation. The purpose of Regional Autonomy according to Law No. 32 of 2004 on Regional Government article 2 paragraph 3 states that the aim of Regional Autonomy is to carry out the widest possible autonomy, except for government affairs, with the aim of improving public welfare, public services, and regional competitiveness. With the existence of Regional Autonomy, it is hoped that the maximum increase in public services from government agencies of each region. With this maximum service, it is hoped that the community can directly experience the benefits of regional autonomy. After receiving optimal service, it is hoped that the community can improve their welfare. By implementing Regional Autonomy, it is hoped that it can increase regional competitiveness and must continue to pay attention to the form of diversity of a region as well as the specificities or specialties of certain regions. One reliable indicator of Regional Autonomy is the Human Development Index, which includes three basic components for human welfare, namely health, education and the economy.

\subsection{Hypothesis}

Research on the relationship or influence of financial performance with community welfare has been carried out both at the district / city government or the provincial government. Research with a sample of provinces in Java found that local income has an effect on people's welfare [1]. Research with a sample of Jambi province found that decentralization and direct spending have an effect on community welfare. [3] Research with a sample of districts / cities in central Sumatra found that the decentralization ratio has an effect on people's welfare [2]. Research with a sample of districts / cities in Bali found that financial performance has an effect on people's welfare [7]. Finally, research with a sample of districts / cities in Indonesia found that regional financial independence has a positive effect on people's welfare. [4] By measuring the results of this study, the hypothesis is built that financial performance affects the welfare of society

\section{Method}

The population in this study were all provincial governments in Indonesia, amounting to 34 provinces. All provinces in this study were sampled. The data used in this study are secondary data in the form of financial statistics of the provincial government in Indonesia within a few years and the Indonesian human development index obtained from the Central Statistics Agency for the period of 2016 to 2019. The analytical tool used in this study is descriptive. 


\section{Results And Discussion}

\subsection{Development of the Human Development Index}

In the last four years, from 2016 to 2019 , the index of human development in Indonesia has always experienced an increase and from 34 provinces all human development indices have also increased. In 2016 there were 12 provinces with high categories, 21 provinces with medium categories, and there were 1 provinces with low categories. In 2017 there were 1 province with a very high category, 14 provinces in the high category, 18 provinces in the medium category and 1 province in the low category. In 2018 there will be no more provinces in Indonesia with a low human development index (score $<60)$. This year there were 1 province with a very high category, 21 provinces with a high category and 12 provinces with a medium category. In 2019 the human development index by province can be grouped into 1 very high province, 22 high provinces and 11 medium provinces.

The growth of the human development index in Indonesia in 2017 compared to the previous year of 0.90 percent, in 2018 grew 0.82 percent and in 2019 grew 0.74 percent. If we look at the growth rate of the human development index in Indonesia, it tends to decrease from year to year. The growth of the human development index by province has a tendency for provinces that are still in the medium category to have a higher growth than provinces that are already in the high category. Several provinces outside Java which are in the medium category have experienced growth of more than 1 percent while provinces that have entered the high category of human development index growth rates tend to be lower at less than 1 percent.

Table 1. Human Development Index and HDI Growth

\begin{tabular}{|c|c|c|c|c|c|c|c|c|}
\hline \multirow[t]{2}{*}{$\mathrm{NO}$} & \multirow[t]{2}{*}{ PROVINCE } & \multicolumn{4}{|c|}{$\begin{array}{l}\text { HUMAN DEVELOPMENT } \\
\text { INDEX }\end{array}$} & \multicolumn{3}{|c|}{ HDI GROWTH } \\
\hline & & 2016 & 2017 & 2018 & 2019 & 2017 & 2018 & 2019 \\
\hline 1 & Aceh & 70.00 & 70.60 & 71.19 & 71.90 & $0.86 \%$ & $0.84 \%$ & $1.00 \%$ \\
\hline 2 & Sumatera Utara & 70.00 & 70.57 & 71.18 & 71.74 & $0.81 \%$ & $0.86 \%$ & $0.79 \%$ \\
\hline 3 & Sumatera Barat & 70.73 & 71.24 & 71.73 & 72.39 & $0.72 \%$ & $0.69 \%$ & $0.92 \%$ \\
\hline 4 & Riau & 71.20 & 71.79 & 71.73 & 73.00 & $0.83 \%$ & $-0.08 \%$ & $1.77 \%$ \\
\hline 5 & Jambi & 69.62 & 69.99 & 70.65 & 71.26 & $0.53 \%$ & $0.94 \%$ & $0.86 \%$ \\
\hline 6 & Sumatera Selatan & 68.24 & 68.86 & 69.39 & 70.02 & $0.91 \%$ & $0.77 \%$ & $0.91 \%$ \\
\hline 7 & Bengkulu & 69.33 & 69.95 & 70.64 & 71.21 & $0.89 \%$ & $0.99 \%$ & $0.81 \%$ \\
\hline 8 & Lampung & 67.65 & 68.25 & 69.39 & 69.57 & $0.89 \%$ & $1.67 \%$ & $0.26 \%$ \\
\hline 9 & Bangka Belitung & 69.55 & 69.99 & 70.67 & 71.30 & $0.63 \%$ & $0.97 \%$ & $0.89 \%$ \\
\hline 10 & Kepulauan Riau & 73.99 & 74.45 & 74.85 & 75.40 & $0.62 \%$ & $0.54 \%$ & $0.73 \%$ \\
\hline 11 & DKI Jakarta & 79.60 & 80.06 & 80.47 & 80.76 & $0.58 \%$ & $0.51 \%$ & $0.36 \%$ \\
\hline 12 & Jawa Barat & 70.05 & 70.69 & 71.30 & 72.03 & $0.91 \%$ & $0.86 \%$ & $1.02 \%$ \\
\hline 13 & Jawa Tengah & 69.98 & 70.52 & 71.12 & 71.73 & $0.77 \%$ & $0.85 \%$ & $0.86 \%$ \\
\hline 14 & D.I Yogyakarta & 78.38 & 78.89 & 79.53 & 79.99 & $0.65 \%$ & $0.81 \%$ & $0.58 \%$ \\
\hline 15 & Jawa Timur & 69.74 & 70.27 & 70.77 & 71.50 & $0.76 \%$ & $0.71 \%$ & $1.03 \%$ \\
\hline 16 & Banten & 70.96 & 71.42 & 71.95 & 72.44 & $0.65 \%$ & $0.74 \%$ & $0.68 \%$ \\
\hline
\end{tabular}




\begin{tabular}{|c|c|c|c|c|c|c|c|c|}
\hline 17 & Bali & 73.65 & 74.30 & 74.77 & 75.38 & $0.88 \%$ & $0.63 \%$ & $0.82 \%$ \\
\hline 18 & $\begin{array}{l}\text { Nusa Tenggara } \\
\text { Barat }\end{array}$ & 65.81 & 66.58 & 67.30 & 68.14 & $1.17 \%$ & $1.08 \%$ & $1.25 \%$ \\
\hline 19 & $\begin{array}{l}\text { Nusa Tenggara } \\
\text { Timur }\end{array}$ & 63.13 & 63.73 & 64.39 & 65.23 & $0.95 \%$ & $1.04 \%$ & $1.30 \%$ \\
\hline 20 & Kalimantan Barat & 65.88 & 66.26 & 66.98 & 67.65 & $0.58 \%$ & $1.09 \%$ & $1.00 \%$ \\
\hline 21 & Kalimantan Tengah & 69.13 & 69.79 & 70.42 & 70.91 & $0.95 \%$ & $0.90 \%$ & $0.70 \%$ \\
\hline 22 & Kalimantan Selatan & 69.05 & 69.65 & 70.17 & 70.72 & $0.87 \%$ & $0.75 \%$ & $0.78 \%$ \\
\hline 23 & Kalimantan Timur & 74.59 & 75.12 & 75.83 & 76.61 & $0.71 \%$ & $0.95 \%$ & $1.03 \%$ \\
\hline 24 & Kalimantan Utara & 69.20 & 69.84 & 70.56 & 71.15 & $0.92 \%$ & $1.03 \%$ & $0.84 \%$ \\
\hline 25 & Sulawesi Utara & 71.05 & 71.66 & 72.20 & 72.99 & $0.86 \%$ & $0.75 \%$ & $1.09 \%$ \\
\hline 26 & Sulawesi Tengah & 67.47 & 68.11 & 68.88 & 69.50 & $0.95 \%$ & $1.13 \%$ & $0.90 \%$ \\
\hline 27 & Sulawesi Selatan & 69.76 & 70.34 & 70.90 & 71.66 & $0.83 \%$ & $0.80 \%$ & $1.07 \%$ \\
\hline 28 & Sulawesi Tenggara & 69.31 & 69.86 & 70.61 & 71.20 & $0.79 \%$ & $1.07 \%$ & $0.84 \%$ \\
\hline 29 & Gorontalo & 66.29 & 67.01 & 67.71 & 68.49 & $1.09 \%$ & $1.04 \%$ & $1.15 \%$ \\
\hline 30 & Sulawesi Barat & 63.60 & 64.30 & 65.10 & 65.73 & $1.10 \%$ & $1.24 \%$ & $0.97 \%$ \\
\hline 31 & Maluku & 67.60 & 68.19 & 68.87 & 69.45 & $0.87 \%$ & $1.00 \%$ & $0.84 \%$ \\
\hline 32 & Maluku Utara & 66.63 & 67.20 & 67.76 & 68.70 & $0.86 \%$ & $0.83 \%$ & $1.39 \%$ \\
\hline 33 & Papua Barat & 62.21 & 62.99 & 63.74 & 64.70 & $1.25 \%$ & $1.19 \%$ & $1.51 \%$ \\
\hline \multirow[t]{2}{*}{34} & Papua & 58.05 & 59.09 & 60.06 & 60.84 & $1.79 \%$ & $1.64 \%$ & $1.30 \%$ \\
\hline & Indonesia & 70.18 & 70.81 & 71.39 & 71.92 & $0.90 \%$ & $0.82 \%$ & $0.74 \%$ \\
\hline
\end{tabular}

Source: Central Bureau of Statistics

\subsection{Fiscal Decentralization}

From the realization of the budget data for the provincial government revenue in Indonesia in 2016 to 2018, it appears that the role of balance funds is still very dominant. In 2016 there were 7 provinces whose original regional income contributed more than 50 percent to regional income while the remaining 19 provinces contributed 25 percent to less than 50 percent and 8 provinces contributed less than 25 percent. In 2017 and 2018 the number of provinces whose regional income contributed to regional income more than 50 percent consisted of 8 provinces, the contribution of 25 percent to less than 50 percent was 16 provinces and less than 25 percent consisted of 10 provinces. For three years the contribution of regional own-source revenues to regional income ranged from the lowest 5 percent to the highest 70 percent.

In Law number 33 of 2004 concerning financial balance between the central government and regional governments, it is stated that the Financial Balance between the Government and Regional Governments is a comprehensive system in the framework of funding the implementation of the Decentralization, Deconcentration and Co-Administration Principle. Article 3 (1) Regional original revenue aims to give authority to the Regional Government to fund the implementation of regional autonomy in accordance with the Regional potential as a manifestation of Decentralization. (2) The Balancing Fund aims to reduce the fiscal gap between the Government and Regional Governments and among Regional Governments.

From these data it shows that so far the provincial government in Indonesia is still largely dependent on funding sourced from the central government in the form of balancing funds, 
both general allocation funds, special allocation funds and revenue sharing funds both for tax revenue sharing and natural resource revenue sharing. Based on this fact, the government and the people of Indonesia should realize that now is not the right time to propose an expansion by forming a new autonomous region. If it is forced on the grounds of fulfilling the aspirations of the people it will only benefit the elite who get power over the new autonomous region but it will become a burden on the government and must be borne by all the people of Indonesia.

Table 2. The Contribution of Original Regional Revenue and Balancing Funds to Regional Revenues

\begin{tabular}{|c|c|c|c|c|c|c|c|}
\hline \multirow[t]{2}{*}{$\mathrm{NO}$} & \multirow[t]{2}{*}{ PROVINSI } & \multicolumn{3}{|c|}{ PAD } & \multicolumn{3}{|c|}{ DANA TRANSFER } \\
\hline & & 2016 & 2017 & 2018 & 2016 & 2017 & 2018 \\
\hline 1 & Aceh & $16.66 \%$ & $15.86 \%$ & $16.35 \%$ & $12.72 \%$ & $26.50 \%$ & $25.89 \%$ \\
\hline 2 & Sumatera Utara & $47.46 \%$ & $43.22 \%$ & $44.39 \%$ & $49.99 \%$ & $56.63 \%$ & $55.54 \%$ \\
\hline 3 & Sumatera Barat & $42.47 \%$ & $35.18 \%$ & $36.16 \%$ & $55.72 \%$ & $63.73 \%$ & $62.47 \%$ \\
\hline 4 & Riau & $44.80 \%$ & $42.52 \%$ & $42.92 \%$ & $55.08 \%$ & $57.44 \%$ & $56.94 \%$ \\
\hline 5 & Jambi & $37.21 \%$ & $36.71 \%$ & $37.54 \%$ & $43.64 \%$ & $63.25 \%$ & $62.22 \%$ \\
\hline 6 & Sumatera Selatan & $38.68 \%$ & $36.99 \%$ & $38.59 \%$ & $38.07 \%$ & $49.55 \%$ & $60.31 \%$ \\
\hline 7 & Bengkulu & $31.06 \%$ & $28.69 \%$ & $30.59 \%$ & $68.62 \%$ & $71.24 \%$ & $51.83 \%$ \\
\hline 8 & Lampung & $42.39 \%$ & $40.37 \%$ & $40.35 \%$ & $56.52 \%$ & $59.12 \%$ & $39.67 \%$ \\
\hline 9 & Bangka Belitung & $29.45 \%$ & $31.53 \%$ & $33.26 \%$ & $57.77 \%$ & $43.55 \%$ & $39.83 \%$ \\
\hline 10 & Kepulauan Riau & $36.44 \%$ & $33.66 \%$ & $34.88 \%$ & $51.35 \%$ & $66.30 \%$ & $65.09 \%$ \\
\hline 11 & DKI Jakarta & $68.58 \%$ & $67.72 \%$ & $70.75 \%$ & $28.39 \%$ & $29.26 \%$ & $29.16 \%$ \\
\hline 12 & Jawa Barat & $61.54 \%$ & $56.22 \%$ & $57.91 \%$ & $38.36 \%$ & $43.47 \%$ & $41.89 \%$ \\
\hline 13 & Jawa Tengah & $58.79 \%$ & $52.94 \%$ & $55.51 \%$ & $40.84 \%$ & $46.69 \%$ & $44.26 \%$ \\
\hline 14 & D.I Yogyakarta & $42.93 \%$ & $36.42 \%$ & $37.56 \%$ & $43.52 \%$ & $46.80 \%$ & $42.65 \%$ \\
\hline 15 & Jawa Timur & $63.37 \%$ & $58.01 \%$ & $58.02 \%$ & $36.21 \%$ & $41.84 \%$ & $41.63 \%$ \\
\hline 16 & Banten & $63.11 \%$ & $59.31 \%$ & $61.33 \%$ & $36.80 \%$ & $40.49 \%$ & $38.55 \%$ \\
\hline 17 & Bali & $57.94 \%$ & $56.72 \%$ & $59.41 \%$ & $35.57 \%$ & $42.32 \%$ & $39.84 \%$ \\
\hline 18 & $\begin{array}{l}\text { Nusa Tenggara } \\
\text { Barat }\end{array}$ & $34.43 \%$ & $33.14 \%$ & $33.60 \%$ & $65.39 \%$ & $64.31 \%$ & $65.01 \%$ \\
\hline 19 & $\begin{array}{l}\text { Nusa Tenggara } \\
\text { Timur }\end{array}$ & $25.68 \%$ & $22.29 \%$ & $22.91 \%$ & $73.27 \%$ & $77.52 \%$ & $76.98 \%$ \\
\hline 20 & Kalimantan Barat & $37.03 \%$ & $36.10 \%$ & $38.78 \%$ & $41.40 \%$ & $63.46 \%$ & $60.86 \%$ \\
\hline 21 & Kalimantan Tengah & $32.64 \%$ & $32.73 \%$ & $34.53 \%$ & $52.95 \%$ & $63.18 \%$ & $62.11 \%$ \\
\hline 22 & Kalimantan Selatan & $47.90 \%$ & $50.83 \%$ & $53.96 \%$ & $40.15 \%$ & $48.39 \%$ & $45.30 \%$ \\
\hline 23 & Kalimantan Timur & $50.46 \%$ & $56.27 \%$ & $54.36 \%$ & $49.36 \%$ & $43.32 \%$ & $45.27 \%$ \\
\hline 24 & Kalimantan Utara & $21.77 \%$ & $21.71 \%$ & $23.72 \%$ & $67.70 \%$ & $74.05 \%$ & $75.41 \%$ \\
\hline 25 & Sulawesi Utara & $30.88 \%$ & $30.73 \%$ & $33.17 \%$ & $65.19 \%$ & $67.21 \%$ & $66.28 \%$ \\
\hline 26 & Sulawesi Tengah & $29.57 \%$ & $26.34 \%$ & $26.19 \%$ & $69.61 \%$ & $72.76 \%$ & $70.38 \%$ \\
\hline 27 & Sulawesi Selatan & $48.16 \%$ & $40.63 \%$ & $42.67 \%$ & $51.65 \%$ & $59.13 \%$ & $57.15 \%$ \\
\hline 28 & Sulawesi Tenggara & $26.92 \%$ & $22.81 \%$ & $23.88 \%$ & $72.50 \%$ & $75.70 \%$ & $75.69 \%$ \\
\hline
\end{tabular}




\begin{tabular}{llcccccc}
\hline 29 & Gorontalo & $19.64 \%$ & $19.64 \%$ & $21.36 \%$ & $77.79 \%$ & $79.91 \%$ & $77.67 \%$ \\
30 & Sulawesi Barat & $13.48 \%$ & $16.21 \%$ & $16.57 \%$ & $83.44 \%$ & $83.65 \%$ & $82.32 \%$ \\
31 & Maluku & $21.89 \%$ & $15.29 \%$ & $15.15 \%$ & $74.68 \%$ & $84.14 \%$ & $84.55 \%$ \\
32 & Maluku Utara & $13.85 \%$ & $14.39 \%$ & $14.40 \%$ & $71.86 \%$ & $82.63 \%$ & $84.40 \%$ \\
33 & Papua Barat & $5.03 \%$ & $6.62 \%$ & $6.28 \%$ & $47.80 \%$ & $46.97 \%$ & $38.87 \%$ \\
34 & Papua & $8.11 \%$ & $7.81 \%$ & $6.92 \%$ & $28.61 \%$ & $29.07 \%$ & $33.03 \%$ \\
& Average & $36.77 \%$ & $34.87 \%$ & $36.00 \%$ & $52.43 \%$ & $57.75 \%$ & $55.85 \%$ \\
\hline
\end{tabular}

\section{a. Regional Expenditure}

To be able to improve community welfare, the government is not only demanded to explore maximum revenue by optimizing the economic potential of the region so that optimal economic resources are available as basic capital in developing regions. No less important than the management of regional income is regional expenditure. Regional expenditure activities are about what the main regional government does in accordance with the vision and mission of the regional head promised in the regional head election event. The regional head together with the regional legislative council will try to realize the promises of his campaign to be able to meet the expectations of the people in the area he leads.

Regional expenditure consists of two major groups, namely indirect shopping and direct shopping. Indirect expenditure is a routine regional expenditure in the context of providing services to the public. Regional expenditure in the form of indirect expenditure consists of employee expenditure, interest expenditure, subsidy expenditure, grant expenditure, social assistance expenditure, unexpected expenditure. Of all types of indirect shopping, employee spending takes the largest portion, which usually ranges from 70 percent of indirect expenditure. Direct expenditure is regional expenditure directly related to the planned development program in the regional income and expenditure budget. Regional expenditure consists of personnel expenditure, goods and services expenditure, and capital expenditure

During 2016 to 2018 the average indirect expenditure of the provincial government in Indonesia was 52 to 55 percent, meaning that this routine expenditure took a bigger portion compared to direct expenditure, which ranged from 45 to 48 percent of total regional expenditure.

Tabel 3. Proportion of Indirect and Direct Expenditure

\begin{tabular}{llcccccc}
\hline NO & PROVINCE & \multicolumn{3}{c}{ Indirect Expenditure } & \multicolumn{3}{c}{ Direct Expendture } \\
\hline & & 2016 & 2017 & 2018 & 2016 & 2017 & 2018 \\
1 & Aceh & $13.23 \%$ & $25.13 \%$ & $31.87 \%$ & $86.77 \%$ & $74.87 \%$ & $68.13 \%$ \\
2 & Sumatera Utara & $74.26 \%$ & $65.30 \%$ & $69.89 \%$ & $25.74 \%$ & $34.70 \%$ & $30.11 \%$ \\
3 & Sumatera Barat & $57.74 \%$ & $63.65 \%$ & $58.25 \%$ & $42.26 \%$ & $36.35 \%$ & $41.75 \%$ \\
4 & Riau & $51.05 \%$ & $53.75 \%$ & $61.51 \%$ & $48.95 \%$ & $46.25 \%$ & $38.49 \%$ \\
5 & Jambi & $50.06 \%$ & $54.35 \%$ & $57.31 \%$ & $49.94 \%$ & $45.65 \%$ & $42.69 \%$ \\
6 & Sumatera Selatan & $71.83 \%$ & $58.52 \%$ & $63.26 \%$ & $28.17 \%$ & $41.48 \%$ & $36.74 \%$ \\
7 & Bengkulu & $53.91 \%$ & $52.32 \%$ & $54.45 \%$ & $46.09 \%$ & $47.68 \%$ & $45.55 \%$ \\
8 & Lampung & $60.93 \%$ & $57.47 \%$ & $57.64 \%$ & $39.07 \%$ & $42.53 \%$ & $42.36 \%$ \\
9 & Bangka Belitung & $58.43 \%$ & $56.38 \%$ & $57.53 \%$ & $41.57 \%$ & $43.62 \%$ & $42.47 \%$ \\
\hline
\end{tabular}




\begin{tabular}{|c|c|c|c|c|c|c|c|}
\hline 10 & Kepulauan Riau & $53.67 \%$ & $56.13 \%$ & $43.16 \%$ & $46.33 \%$ & $43.87 \%$ & $56.84 \%$ \\
\hline 11 & DKI Jakarta & $48.35 \%$ & $46.48 \%$ & $49.46 \%$ & $51.65 \%$ & $53.52 \%$ & $50.54 \%$ \\
\hline 12 & Jawa Barat & $78.74 \%$ & $78.90 \%$ & $76.86 \%$ & $21.26 \%$ & $21.10 \%$ & $23.14 \%$ \\
\hline 13 & Jawa Tengah & $70.87 \%$ & $76.84 \%$ & $73.72 \%$ & $29.13 \%$ & $23.16 \%$ & $26.28 \%$ \\
\hline 14 & D.I Yogyakarta & $51.94 \%$ & $52.16 \%$ & $49.87 \%$ & $48.06 \%$ & $47.84 \%$ & $50.13 \%$ \\
\hline 15 & Jawa Timur & $68.65 \%$ & $67.24 \%$ & $68.80 \%$ & $31.35 \%$ & $32.76 \%$ & $31.20 \%$ \\
\hline 16 & Banten & $65.38 \%$ & $66.90 \%$ & $64.94 \%$ & $34.62 \%$ & $33.10 \%$ & $35.06 \%$ \\
\hline 17 & Bali & $71.16 \%$ & $71.63 \%$ & $74.94 \%$ & $28.84 \%$ & $28.37 \%$ & $25.06 \%$ \\
\hline 18 & $\begin{array}{l}\text { Nusa Tenggara } \\
\text { Barat }\end{array}$ & $60.39 \%$ & $50.68 \%$ & $54.62 \%$ & $39.61 \%$ & $49.32 \%$ & $45.38 \%$ \\
\hline 19 & $\begin{array}{l}\text { Nusa Tenggara } \\
\text { Timur }\end{array}$ & $64.63 \%$ & $66.53 \%$ & $66.41 \%$ & $35.37 \%$ & $33.47 \%$ & $33.59 \%$ \\
\hline 20 & Kalimantan Barat & $63.14 \%$ & $53.11 \%$ & $67.87 \%$ & $36.86 \%$ & $46.89 \%$ & $32.13 \%$ \\
\hline 21 & $\begin{array}{l}\text { Kalimantan } \\
\text { Tengah }\end{array}$ & $51.42 \%$ & $58.76 \%$ & $52.22 \%$ & $48.58 \%$ & $41.24 \%$ & $47.78 \%$ \\
\hline 22 & $\begin{array}{l}\text { Kalimantan } \\
\text { Selatan }\end{array}$ & $44.63 \%$ & $50.03 \%$ & $52.50 \%$ & $55.37 \%$ & $49.97 \%$ & $47.50 \%$ \\
\hline 23 & Kalimantan Timur & $53.03 \%$ & $62.95 \%$ & $60.37 \%$ & $46.97 \%$ & $37.05 \%$ & $39.63 \%$ \\
\hline 24 & Kalimantan Utara & $38.99 \%$ & $39.06 \%$ & $38.19 \%$ & $61.01 \%$ & $60.94 \%$ & $61.81 \%$ \\
\hline 25 & Sulawesi Utara & $51.85 \%$ & $55.56 \%$ & $58.17 \%$ & $48.15 \%$ & $44.44 \%$ & $41.83 \%$ \\
\hline 26 & Sulawesi Tengah & $48.63 \%$ & $57.27 \%$ & $58.09 \%$ & $51.37 \%$ & $42.73 \%$ & $41.91 \%$ \\
\hline 27 & Sulawesi Selatan & $66.88 \%$ & $66.63 \%$ & $70.14 \%$ & $33.12 \%$ & $33.37 \%$ & $29.86 \%$ \\
\hline 28 & Sulawesi Tenggara & $55.06 \%$ & $58.86 \%$ & $60.86 \%$ & $44.94 \%$ & $41.14 \%$ & $39.14 \%$ \\
\hline 29 & Gorontalo & $48.07 \%$ & $53.91 \%$ & $53.00 \%$ & $51.93 \%$ & $46.09 \%$ & $47.00 \%$ \\
\hline 30 & Sulawesi Barat & $46.74 \%$ & $50.16 \%$ & $54.31 \%$ & $53.26 \%$ & $49.84 \%$ & $45.69 \%$ \\
\hline 31 & Maluku & $43.55 \%$ & $55.02 \%$ & $57.57 \%$ & $56.45 \%$ & $44.98 \%$ & $42.43 \%$ \\
\hline 32 & Maluku Utara & $38.34 \%$ & $44.03 \%$ & $50.26 \%$ & $61.66 \%$ & $55.97 \%$ & $49.74 \%$ \\
\hline 33 & Papua Barat & $50.89 \%$ & $62.68 \%$ & $53.44 \%$ & $49.11 \%$ & $37.32 \%$ & $46.56 \%$ \\
\hline \multirow[t]{2}{*}{34} & Papua & $56.67 \%$ & $57.24 \%$ & $66.63 \%$ & $43.33 \%$ & $42.76 \%$ & $33.37 \%$ \\
\hline & Average & $55.39 \%$ & $57.22 \%$ & $58.47 \%$ & $44.61 \%$ & $42.78 \%$ & $41.53 \%$ \\
\hline
\end{tabular}

\section{Conclusion}

From the discussion above it can be concluded as follows "

1. Human development index in Indonesia increases from year to year with a growth rate that tends to decline

2. The level of dependence of the provincial government on fund transfers from the central government is still very high

3. The portion of indirect expenditure of the provincial government is greater than the portion of direct expenditure. 
The descriptive analysis tool used in this study cannot provide accurate results in explaining the effect of financial performance on people's welfare. The research object of the provincial government can also be a limitation in this study considering that regional autonomy focuses on the district / city government. In connection with these limitations, the next suggested research agenda is to use more precise analytical tools and research objects in regencies / cities.

\section{References}

[1] Aniek Juliarini, Kinerja Pendapatan Daerah Terhadap Indeks Pembangunan Manusia Studi Kasus Provinsi Di Pulau Jawa, Snkn 2018 | Simposium Nasional Keuangan Negara

[2] Desi Handayani Dan Fera Sriyunianti, Analisa Kinerja Keuangan Terhadap Indeks Pembangunan Manusia Kabupaten Kota Di Sumatera Bagian Tengah, National Conference Of Applied Sciences, Engineering, Business And Information Technology. Politeknik Negeri Padang, 15 - 16 Oktober 2016

[3] Eka Marisca Harliyani; Haryadi, Pengaruh Kinerja Keuangan Pemerintah Daerah Terhadap Indeks Pembangunan Manusia Di Provinsi Jambi, Jurnal Perspektif Pembiayaan Dan Pembangunan Daerah Vol. 3 No. 3, Januari-Maret 2016 Issn: 2338-4603 (Print); 2355-8520 (Online )

[4] Khairudin1*, Rosmiati Tarmizi2, Indrayenti3, Aminah4, Kinerja Keuangan Dan Kesejahteraan Masyarakat Pemerintah Daerah Di Indonesia, Ajie - Asian Journal Of Innovation And Entrepreneurship (E-Issn: 2477-0574; P-Issn: 2477-3824) Vol. 04, Issue. 03, September 2019

[5] Maryono, Ida Nurhayati And Batara Daniel Bagana, Map Of Financial Capabilities Of The Provincial Region In Indonesia, Advances In Economics, Business And Management Research, Volume 86 2nd International Conference On Banking, Accounting, Management And Economics (Icobame 2018

[6] Nugraha Dan Tia Amelia, Pengaruh Dana Perimbangan Dan Kemandirian Keuangan Daerah Terhadap Kesejahteraan Masyarakat Pada Kabupaten Dan Kota Di Jawa Barat Tahun 2011-2014, Jurnal Wacana Kinerja Volume 20 | Nomor 1 | Juni 2017

[7] Ni Nyoman Suryaningsih, Made Suyana Utama, I.N. Mahaendra Yasa3 , Dampak Kinerja Keuangan Daerah Terhadapkesejahteraan Masyarakat Kabupaten/Kotadi Provinsi Bali, E-Jurnal Ekonomi Dan Bisnis Universitas Udayana 4.08 (2015) : 537-554

[8] Wayan Marayadnya1, Mohammad Iqbal B Dan Muh Ikbal A. Analisis Kinerja Keuangan Dan Tingkat Kesejahteraan Masyarakat Kabupaten Donggala, E Jurnal Katalogis, Volume 6 Nomor 2 Februari 2018 Hlm 73-85 